\title{
A Midsummer Night's Dream in Polish Puppet Theatres in Silesia - Mise-en-scène by Jan Dorman, Josef Krofta and Marián Pecko
}

Ewa Tomaszewska

\begin{abstract}
This article presents 3 performances based on Shakespeare's play: A MidsummerNight's Dream made for the Teatr Dzieci Zagłębia (The Zaglebie Children's Theatre) in Będzin (1965), Wrocław Puppet Theatre (2003) and in the Puppet Theatre 'Banialuka' in Bielsko-Biała (2013). They were created by the famous Polish creator, Jan Dorman and two artistic teams: Czech - under the direction of Josef Krofta, and Slovak - directed by Marián Pecko.

The description of the three performances is presented in the context of the significant presence of artists from the Czech Republic and Slovakia on puppet theatre stages in Poland. Polish, Czech and Slovak puppetry collaboration became a reality at the end of the 1970s and took on a new quality after 1992. In Polish theatres at this time appeared stage directors such as: Brožek, Chalupová-Pěničková, Kopecký (Matěj, father and son), Krofta (Josef and Jakub), Nosálek, Pecko, Spišak, Štumpf; stage designers: Andraško, Doležal, Farkašova, Hubička, Lipták, Kalfus, Kuchinka, Kudlička, Polívka, Tománek, Volkmer, Zákostelecký, Zavarský; and composers: Mankovecký, Helebrand, Engonidis. At the same time, Czech artists such as Karel Brožek, Petr Nosálek, Jakub Krofta, became artistic directors of Polish puppet theatres in Katowice and Wrocław, which was an unprecedented phenomenon.
\end{abstract}

\section{Keywords}

puppet theatre, A Midsummer Night's Dream, Jan Dorman, Josef Krofta, Marián Pecko, Polish-Czech-Slovak theatrical cooperation 


\section{Introduction: Polish-Czech-Slovak Theatre Collaboration}

The beginning of the 1970s saw the origin of cooperation between Polish puppet theatres and theatre artists from Czechoslovakia. The staging of Jánošik in 1975, which was the result of cooperation between three theatres: the Czech company Drak [Dragon] from Hradec Králové, Krajské Bábkové Divadlo from Banská Bystrica and Puppet and Actor Theatre Marcinek from Poznan, proved to be the original impulse for the PolishCzechoslovakian and then Polish-Czech-Slovak contacts. Josef Krofta, Karel Brožek (invited by the Slovaks) and Leokadia Serafinowicz with Wojciech Wieczorkiewicz met during the realisation of this performance. ${ }^{1}$ The Polish-Czech-Slovak folk hero, Jánošík, was the anchor binding the three nations in this artistic theatrical adventure. ${ }^{2}$

This tri-national project led to a different kind of collaboration - Czech creators came to Poland to realise their artistic ideas on Polish stages.

The first was Josef Krofta who in the Poznan theatre Marcinek found a space less restraining of his creativity:

The political conditions in Czechoslovakia limited the artistic freedom of theatres to classic or folk subjects, cutting them off from all great humanistic subjects. It was probably on that account that in 1976 in the Poznan Puppet Theatre he directed Don Quixote in his own adaptation. In this performance Krofta developed his own style, shattering the theatre reality and replacing it with a metaphor. The performance was realised by actors who occasionally made use of puppets either as signs or their doubles. Thus a world of pulsating signs which the spectator interpreted as the show progressed was created. Most representative in this respect was the scene of Don Quixote's flogging in which an assistant whipped an empty bench, an actor - Don Quixote - writhed in pain, another actor broke the puppet's limbs and still another groaned. In this way a complete atomisation of the stage image occurred. To a large extent it was remindful of earlier experiments in visual arts. (JURKOWSKI 2002: 127)

The performance revealed the tragedy of a captive hero who in the name of humanistic values undertook an unequal battle against the system. This was unacceptable to the Czech authorities of that time. It was only after 18 years, already in a new socialpolitical reality (1994), that Krofta could stage Don Quixote in the Czech Republic. ${ }^{3}$

1 'It was indeed an international undertaking, very fortunate for all of us. We became very friendly'- says Karel Brožek. Josef Krofta reminisces: 'I consider my collaboration with Wojtek Wieczorkiewicz and Leokadia Serafinowicz one of the most creative and most beautiful realisations.' (KOZIEŃ 1992: 71)

2 It's worth mentioning that after 35 years this project was repeated. In 2010 Warsaw's Lalka theatre, Drak theatre from Hradec Králové and Stare Divadlo Karola Spišaka from Nitra staged Jánošik Janosik Jánošik, a production consisting of three independently prepared performances. It was an attempt to combine three cultures, three conventions and three languages into a coherent feature show.

3 In an interview for Życie Warszawy (3. 4. 2004) Krofta said: 'I am fond of your theatre and your country. I first came to Poland 30 years ago. In Poznan's Marcinek theatre I realised, among other titles, Don Quixote. In the difficult times of communism, I found in the Poles a strong sense of independence strengthened by the Church and art. At that time a puppet theatre was the only stage on which I was allowed to work. It was meant as a punishment. It turned out to be a fortunate turn of fate' (KROFTA 2004). 
At the turn from the seventies into the eighties, despite an unfavourable political atmosphere, Karel Brožek also directed in Poznan. ${ }^{4}$ In 1991, thanks to the then artistic director of the Silesian Puppet and Actor Theatre Ateneum, Maciej. K. Tondera, he came to Katowice where he realised 11 premieres. On September 1, 2007 Brožek became the deputy artistic director there and stayed till the end of the 2011/12 season. For the first time in history a foreigner was in charge of a Polish stage. After his resignation, the position of an artistic consultant was taken over by another Czech, Petr Nosálek, who collaborated with the theatre in Katowice till his death in 2013. Here, it is worth mentioning that, starting from the 2012/13 season, the post of the artistic director, selected by way of competition, of another Polish stage - the Wroclaw Puppet Theatre - has been held by Jakub Krofta.

Polish-Czech-Slovak artistic encounters have intensified since the 1980s. In Walbrzych Matěj Kopecký together with Jaroslav Doležal realized Johannes Doctor Faustus (1980). At the turn of the 80s and 90s Matěj Kopecký, Jr. directed several performances on the same stage. Miroslav Vildman staged his performances in puppet theatres in Bielsko-Biała and Opole. Thanks to him Petr Nosálek from Ostrava arrived in Poland and stayed for a long time. In 2005 the stage designer and director Marek Zákostelecký arrived in Warsaw together with Jakub Krofta, and in 2010 Libor Štumpf came to the Zdrojowy Theatre of Animation in Jelenia Góra. Simona Chalupová-Pěničková from Chrudim staged two plays in the Puppet Theatre Arlekin in Lodz (2005, 2007); she also worked with the Olsztyn Puppet Theatre (2007) and Cracow's Groteska (2008). All these creators brought along their teams. Czech stage designers (Pavel Hubička, Václav Kábrt, Pavel Kalfus, Lukáš Kuchinka, Jan Polívka, Alois Tománek, Tomáš Volkmer) gained enormous popularity in Poland.

From the nineties onwards, Slovak creators also began to arrive in Poland. First, Ondrej Spišak and František Lipták came to the Warsaw theatre Lalka. Then, in 1995, Marián Pecko arrived with his team: Eva Farkašová, Ján Zavarský and Róbert Mankovecký, later joined by Pavol Andraško.

The intensive Polish-Czech-Slovak collaboration was, on the Polish side, provoked by admiration for the professionalism of the creators from beyond the Southern border. In turn, the Czechs and Slovaks sought in Poland additional and better earnings as well as greater creative freedom which, after 1992, was being restrained no longer by politics but by economic factors. ${ }^{5}$ The market economy reached the sphere of culture and its negative effect was the imperative for self-financing theatre, possible only

4 J. Středa after N. Gogol, Noc wigilijna [Christmas Eve], premiere 18. 12. 1977; A. Pushkin, Fairy Tales, premiere 15. 1. 1982; M. Pavlik, Stworzenie stońca [The Creation of the Sun], premiere 3. 6.1984

5 Eva Farkašová says: 'Poliaci sú väčší národ s väčším počtom divadiel a hlbšou tradíciou divadla, vlastnej kultúry a aristokracie. Je to tak dodnes. Aj polské divadlá v súčasnosti bojujú o financie, no nevšimla som si, že by viditelne obmedzovali premiéry alebo odmietli moju scénografiu ako pridrahú.

[The Poles are historically a larger nation with a greater number of theatres and a deeper tradition of theatre, culture and aristocracy. It's still the case today. Also, Polish theatres are currently struggling financially, but I have not noticed that they would visibly restrict premières or refuse my scenography as a pride.]' (FARKAŠOVÁ 2011) 
with very limited casts and low budget productions; ${ }^{6}$ or through staging commercial shows which often led to lowering of standards to suit audience tastes. ${ }^{7}$

\section{Puppet Shows for Adult Audiences}

After WWII in the Peoples' Democracies puppet theatre had a defined audience - children. This was true particularly in the case of state theatres, financed by ministries and required to present productions in accordance with official ideology in which puppets played didactic and educational roles. Thus, on one hand, puppet theatres were subject to both repertoire and ideological restrictions, on the other, however, their activities were not as strictly controlled by the authorities because theatre for children was considered art with a small 'a' and puppeteers were seen as a second category of creator. ${ }^{8}$ An unintentional effect which resulted from such a policy was the much greater creative freedom which Polish puppeteers unscrupulously took advantage of from nearly the very start. Somewhat later a similar situation arose in Czechoslovakia; Karel Brožek said:

In the 70s puppet theatres were artistically more interesting. Which is why the dramatic theatres began to seek inspiration in the solutions worked out by puppet theatres. Also, many puppet directors realised performances in actors' theatres. Although dramatic actors often treated us with some irony - we came from puppets, they knew that we had more freedom and independence from politics. Possibly because no one treated puppet theatres seriously. (TOMASZEVSKA 2013: 67)

6 Again, it's worth quoting Farkašová: 'Na Slovensku je pät profesionálnych bábkových divadiel, ale kto chce založit rodinu, z platu to neutiahne a z profesie uteká. Bábkové divadlo dnes môže robił iba fanatik bytostne presvedčený o tomto spôsobe výpovede. [There are five professional puppet theaters in Slovakia, but whomsoever wants to start a family is not willing to go without a salary and escapes from the profession. Puppet theater today can only make a fanatic be convinced of this way of thinking.]' (FARKAŠOVÁ 2011)

7 In the article 'Mapa czeskiego lalkarstwa' [A Map of Czech Puppetry] Kateřina Dolenská writes: 'Generally speaking, one can state that contemporary Czech theatre experiences a period of stagnation. Repertory theatres often stick to tried solutions, do not introduce any innovations but realise technically solid performances in which puppets seldom appear. One may get the impression that Czech puppet theatre found itself on the outskirts of world trends. This to a large extent is caused by tragic shortage of funds for culture in general.' (DOLENSKÁ 2010: 7)

8 Theatre for children was outside of the domain of interests of the authorities and theatre circles, e.g. there was no serious, professional criticism, the theory of children's theatre was (and still is) non-existent, there was no dedicated training for puppet artists, there was a battle for the treating puppet actors on a par with drama actors (e.g. in terms of wages). The Guardian theatre blog published a post (23. 10. 2013) in which the author expressed the following opinion: 'An absence of reviews about theatre that is made for and with children, and a reluctance by arts desks and editors to take children's theatre seriously not only suggests that we do not value that particular area of theatre, but that we do not value children and their experience of the world. This shows that the problem is still very much relevant.' (GARDNER 2013) 
Thanks to this, some theatres, against directives, reached for a more serious repertoire. In Poland, for example, in the already mentioned Cracow Groteska theatre, a considerable role was played by performances for adult audience: Jan Drda's Hrátky $s$ črtem [Games with the Devil] (1952), ${ }^{9}$ Gdyby Adam byt Polakie [If Adam Were a Pole] (1955), Sławomir Mrożek's Męczeństwo Piotra Ohey'a [The Martyrdom of Peter Ohey] (1959), ${ }^{10}$ Tadeusz Różewicz's Kartoteka [The Card Index] (1961), or Alfred Jarry's Ubu Roi (1965). In the Arlekin theatre in Lodz, in 1954, Henryk Ryl directed the famed spectacle - Molière's The Doctor in Spite of Himself. It is very likely that this performance inspired the premiere of Lékařem snadno a rychle realized in 1957 on the student stage Loutka at Prague's DAMU (Academy of Performing Arts). In Wroclaw, Jan Dorman realised Don Quixote (1963) and in 1967 a stage for adult audiences opened there. Its premieres were: F. G. Lorca's Momento de Verdad [Moment of Truth] ${ }^{11}$ and Wielki ksiaże [Great Prince] based on Shakespeare's Hamlet ${ }^{12}$. In Poznan Leokadia Serafinowicz reached in 1961 for texts by K. I. Gałczyński, in 1968 by Witkacy, and a year later staged the renowned production of Stanisław Wyspianski's Wesele [The Wedding].

In Czechoslovakia, such repertoire appeared at first only on student stages. It was only in 1969 that it reached repertory theatres: Karel Makonj directed The Misunderstanding by Camus on the stage of Vedené Divadlo in Prague, and Karel Brožek Maeterlinck's The Death of Tintagiles at the Naivní Divadlo in Liberec.

\section{A Midsummer Night's Dream - Jan Dorman (1965)}

In 1965, the stage of The Zaglebie Children's Theatre in Będzin for the first time hosted William Shakespeare's A Midsummer Night's Dream. The performance was directed by Jan Dorman..$^{13}$ The staging idea was innovative and exacted specific acting techniques. Two assumptions suggested the solution. On one hand, open, empty space:

A forest near Athens. In this forest lovers' follies are liberated. Fervent instincts like lianas entwine minds, paralyse reason. Couples wander about the forest, pass each other, can't see, 'something' leads them around the forest. The bewitchment has nothing to do with the density of the forest. Perhaps there is no forest? Perhaps only obsession leads them through the regions of passions? Such reasoning convinced the stage designer. On stage - red, sweeping horizon. Hot. (DORMAN 1967b)

9 Games with the Devil was staged by W. Jarema also in Bielsko-Biała in 1968.

10 It's worth mentioning that it was the first staging of that play, belonging to, at that time avant-garde theatre of the absurd.

11 Adaptation and direction - Andrzej Rettinger.

12 Monodrama adapted and performed by Andrzej Dziedziul.

13 W. Shakespeare, A Midsummer Night's Dream, transl. Konstanty I. Gałczyński, dir. Jan Dorman, stage design Jan Dorman and Jacek Dorman, music Felix Mendelssohn, premiere July 12, 1965. 

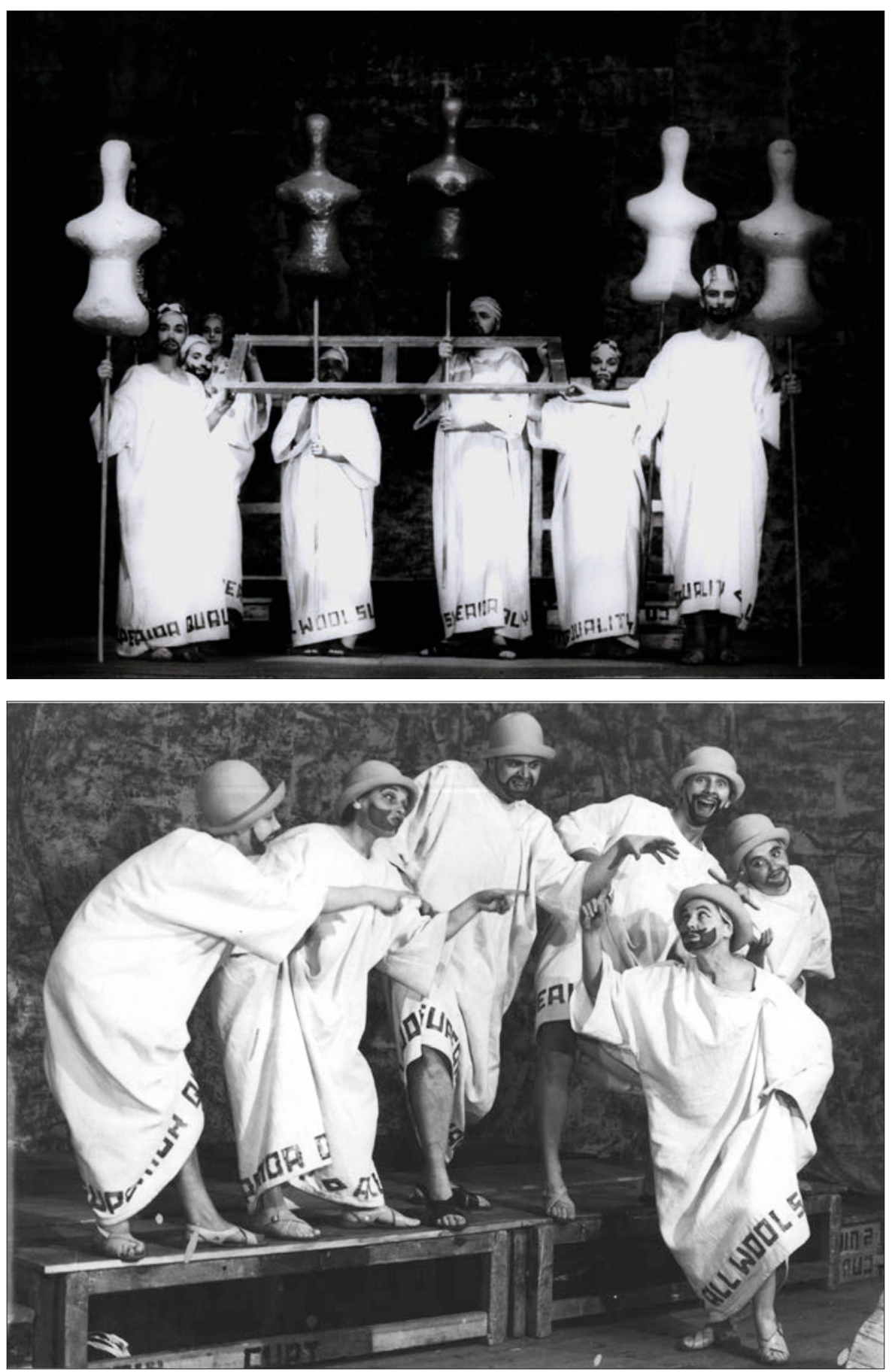

Fig. 1-2: Dorman: Teatr Dzieci Zagłębia in Będzin, 1965 - Archive of Jan Dorman. 


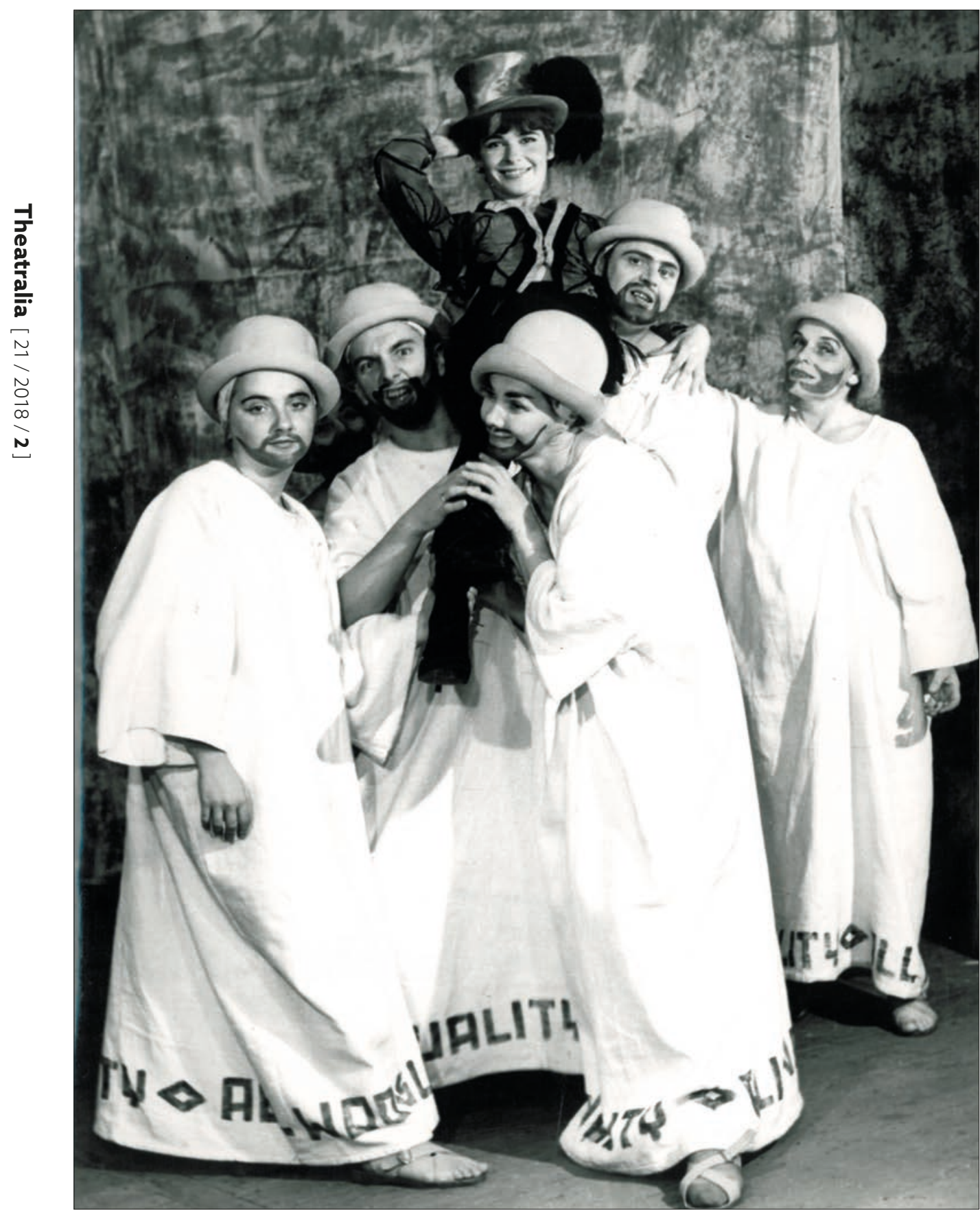

Fig. 3: Dorman: Teatr Dzieci Zagłębia in Będzin, 1965 - Archive of Jan Dorman. 
On the other hand, the small ensemble which Dorman had at his disposal forced the director to cast his actors in double and even triple parts (occasionally women played men's parts). The actors, uniformly dressed in costumes evocative of Greek chitons, played both the Athenian craftsmen rehearsing and performing the play about Pyramus and Thisbe, and the court of Theseus for whom they prepared the play. In order to clearly present this complicated arrangement of a 'theatre within a theatre' Dorman used visual symbols (dummies, masks), formally differentiated movement and rhythmically differentiated speech. The actors, no matter whether men or women, playing the workmen had painted beards - the first step of theatre metaphor. Next, the craftsmen performing the tragedy about Pyramus and Thisbe put on masks, while the craftsmen enacting Theseus and Hippolyta's court, as well as two pairs of lovers, the tangle of whose fates is the main plot of the play, carried huge dummies. They restricted the movements of the actor who thus acquired a kind of solemn rigidity. After putting the dummies aside, the actors hitched up their chitons and playfully rushed onto the platform to act each their particular trade. Everything was based on contrapositions shallowness mixed with loftiness, poetry with bawdy jests (DORMAN 1967b).

The world of gods - Oberon and Titania, spirits and fairies - belonged entirely to a theatre conceived by fin de siècle cabaret. Oberon did not even physically exist on stage - transferred to the sphere of sound, he roared in the wings as a prop used for producing sound effects of a storm. Dorman wrote:

\footnotetext{
Nature for Shakespeare is as mad as law, history, mores. Shakespeare sneers at sentiments, order, resolutions. I sneer at Shakespeare. Shakespeare's Titania is aerial, tender, lyrical. Mine is a common slut. Night is governed by different laws than day and it is in the hallucinations, the phantoms of the night and the censorship of the day that the bitter truth lies. Bitter but human. Love is only dirty. (DORMAN 1971)
}

The startling sense of the staging - an interpretation against love, mocking everything and satiating every scene with gross and sneering laugh - was contained in these words.

\section{Josef Krofta (2003)}

In 2003 Aleksander Maksymiak, at that time the manager of the theatre, invited Josef Krofta to stage a performance of his choice for he believed that a director of Krofta's renown would certainly make the theatre's repertoire more attractive. Krofta proposed Shakespeare, however not an original staging, but a repetition of only slightly modified version of Sen Noci Svatojánské [A Midsummer Night's Dream] realised by him at the Drak Theatre in 1984. The Wroclaw premiere took place on December 21, 2003. ${ }^{14}$

14 W. Shakespeare, A Midsummer Night's Dream, transl. Stanisław Barańczak, adapt. Josef Krofta, Miroslav Klima, dir. Josef Krofta, stage design Dalibor Bača, costumes Jana Bačová-Kroftová, music Zbigniew Kornecki, choreography Jacek Gębura, premiere Wrocław, 21. 12. 2003, Wrocławski Teatr Lalek. 
The adaptation of Shakespeare's text was a far cry from devout respect for the English bard. Entrusted to composer Zbigniew Karnecki with express directives from Krofta, it gained an additional, rock dimension:

Karnecki reduced the talkativeness characteristic for the Stratford genius to refrains of some oldies: from hits by The Animals, Black Sabbath and Cream to a final 'Oh! Darling' by The Beatles. And - perversely - together with Krofta, who trimmed the action to bare minimum, made the spectators remember the words of these old songs. (Gazeta Wyborcza 2004)

The idea was to place the action in the times of hippies and to envelop the entire play in the atmosphere of Woodstock. Long hair and costumes - bell-bottoms and colourful shirts - accented the effect..$^{15}$ The audience faced the back of the stage where a concert took place. They saw the backstage crew in working clothes; later they turned into craftsmen rehearsing the play. They also saw a few crude podiums and vertical cords which later supported a white cloth. The white cloth was a parachute canopy which with the help of cords changed its shape and became either a screen for a shadow theatre or a marker for a place of action. It was a kind of a stage machine, characteristic for Krofta, which changed in front of the spectators and carried them into different theatre spaces. The show featured a specific way of performing - a fusion of live acting with acting with a puppet, acting in a mask and acting with a prop. Shakespeare intended the action to take place in two worlds: the real one - whatever occurred in full sunshine, and the unreal, born out of night's darkness and madness. In Krofta's spectacle, the fantasy world was born in the real one and resembled a dream or a narcotic vision. That was why Titania, Oberon and the world of the fairies, colourful and glowing with magic light, contrasted with the plain, drab world of humans. The hallucinatory character was underlined by costumes resembling those worn when playing ghosts: white sheets with cut-outs for eyes additionally embellished with sewn-in lights which made the fairies glitter like Christmas trees.

Music dominated and lent rhythm to the entire show giving a lot of joy to viewers both young and old most of whom knew the songs. The show was light and full of humour and the audiences had a great time, which could be told by burst of laughter and thunderous applause. The tickets sold very quickly and yet, ultimately, there was something obsolete in the production, a reference to too distant times, while the trimmed story line ended up vague and confusing. At the beginning of the $21^{\text {st }}$ century, young people who were the addressees of the spectacle, formed a number of different subcultures, representing a variety of ideas and styles. For them the hippie times were a subject of their grandparents' stories. At the same time, those who did not know Shakespeare's play had trouble following the plot. Despite a good reception, the show occupied a rather mediocre position in the Wroclaw theatre repertoire. 

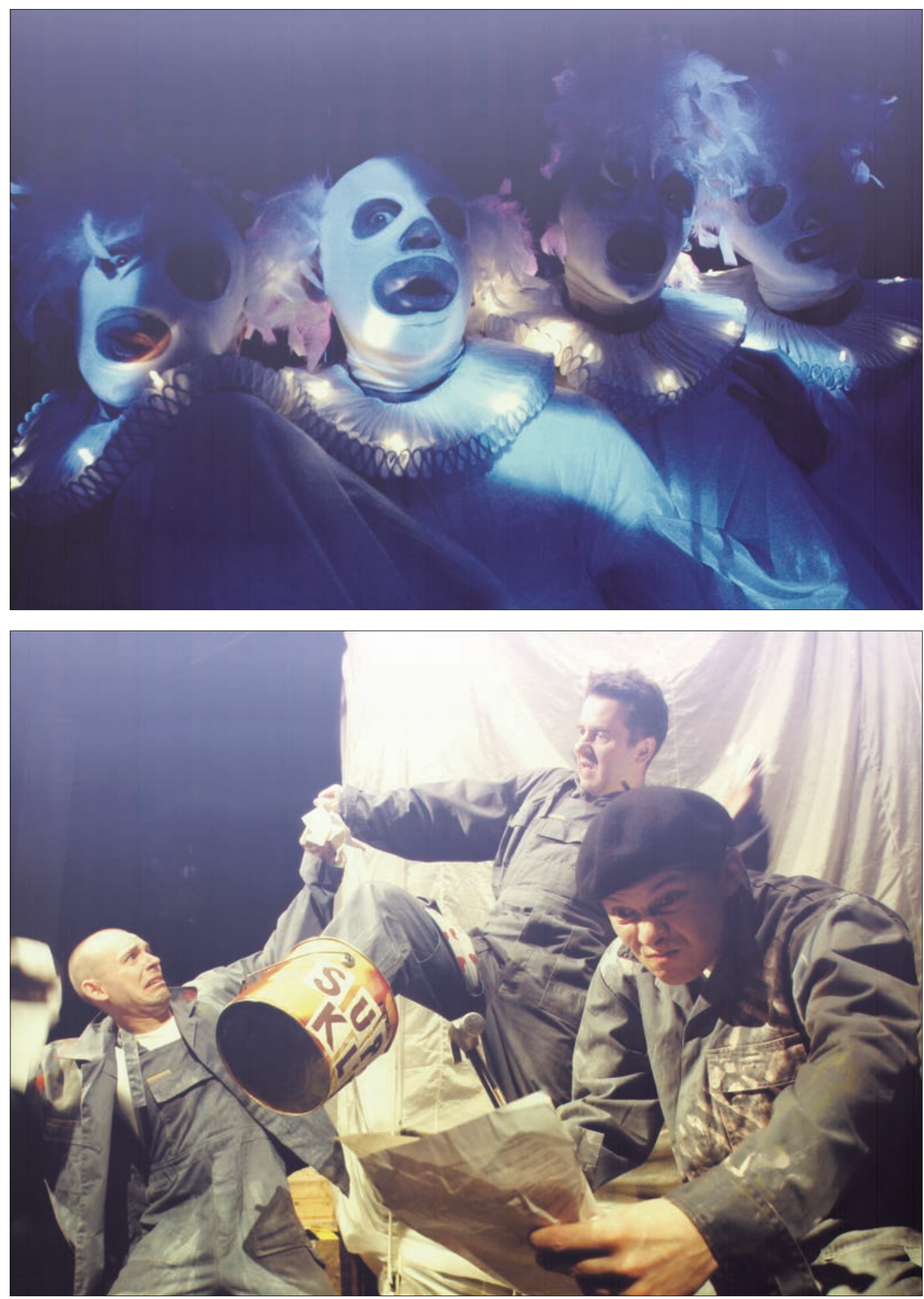

Fig. 4-5: Krofta: Wrocławski Teatr Lalek, Wrocław 2003 - the archive of Puppet Theatre in Wroclaw. 


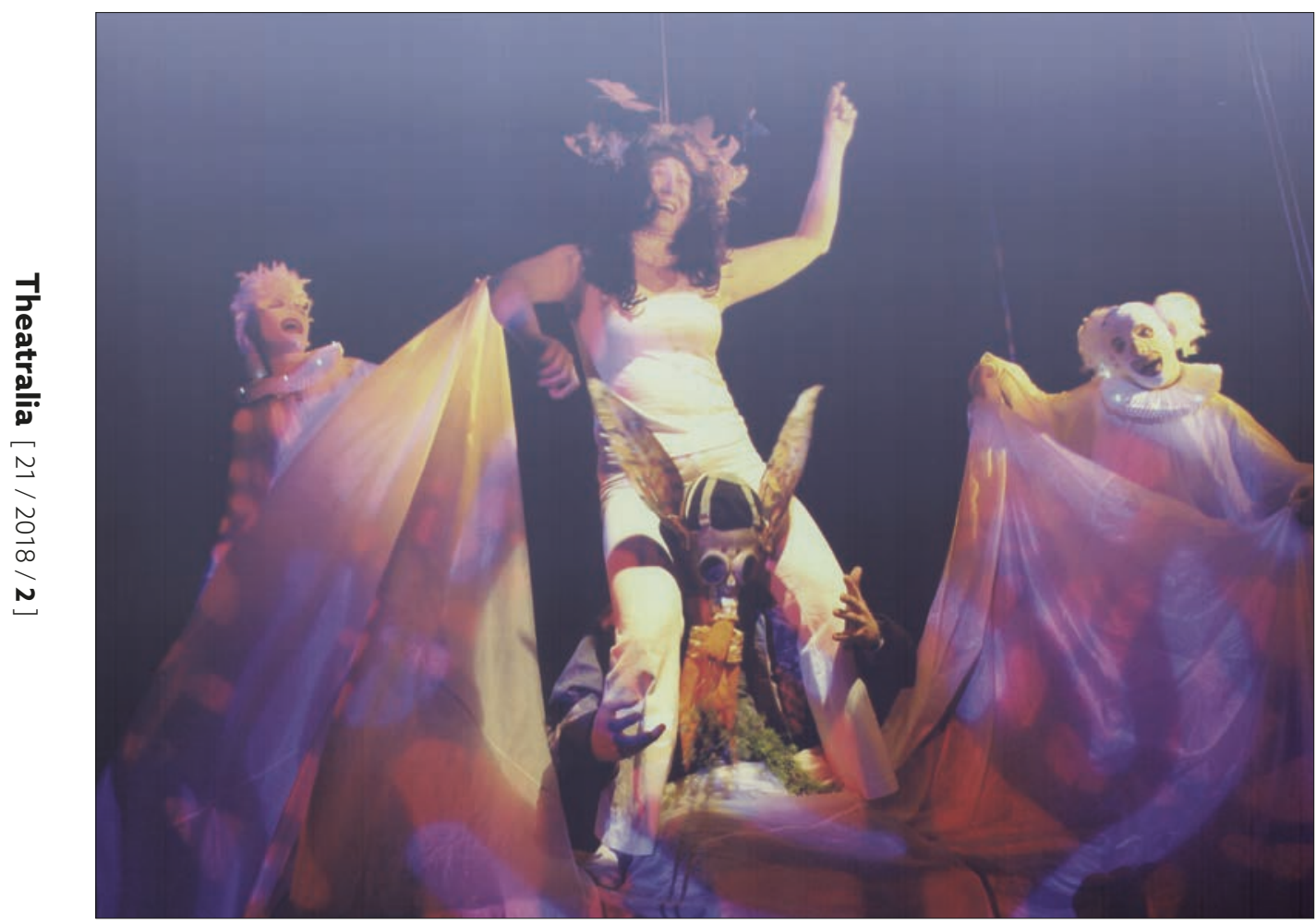

Fig. 6: Krofta: Wrocławski Teatr Lalek, Wrocław 2003 - the archive of Puppet Theatre in Wroclaw.

\section{Marián Pecko (2013)}

Realized ten years later at the Puppet Theatre Banialuka in Bielsko-Biała A Midsummer Night's Dream in this Slovak version ${ }^{16}$ was quite another matter. Although in this case the director, Marián Pecko, also had previous experience with the subject - he staged Sen Noci Svatojánské at the Východočeské divadlo Pardubice theatre ${ }^{17}$ - the original performance, in contrast to the one in Poland, was played mainly in the open air. The event, complemented by acrobatics, stressed the magic and theatricality of the Shakespearian text. In an interview Pecko said:

A Midsummer Night's Dream is a play about theatre, about theatricality, about metamorphoses, dreams, unreal affairs and characters. Everything in it is connected with theatre [...] and

16 W. Shakespeare, A Midsummer Night's Dream, transl. Stanisław Barańczak, dir. Marián Pecko, puppets, costumes: Eva Farkašová, stage design: Pavol Andraško, music Róbert Mankovecký, premiere 19. 4. 2013.

17 W. Shakespeare, A Midsummer Night's Dream, transl. Martin Hilský, adapt. Tomáš Syrovátka, dir. M. Pecko, stage design Pavol Andraško, costumes Eva Farkašová, music Róbert Mankovecký, acrobatics Petr Dejl, premiere 6. 9. 2012. 
that's what interests me. It is also a play about a search for harmony and searching for harmony is one of the most important tasks of theatre and art in general. (SMETANA 2012)

The visual setting and music were created by his regular collaborators: Pavol Andraško, Eva Farkašová and Róbert Mankovecký; they also co-created the Polish production.

The choice of puppets as a means of theatrical expression distinguished Bielsko's Banialuka production from the Czech version. Before the Pardubice premiere, Pecko said:

I even feel like staging A Midsummer Night's Dream in a puppet theatre for it offers more possibilities for choosing means of expression. It is a very theatrical kind of play like, for example, opera [...] With puppets I can accomplish what a human being cannot accomplish. (SMETANA 2012)

This statement indicates that the Czech premiere was a sort of prelude to the puppet version realized in Bielsko-Biała. And, indeed, the performance at the Puppet Theatre Banialuka delighted with a multiplicity of theatrical means, splendours of Baroque artistic visions, and the intermingling of various theatre worlds. Shoddiness merged with loftiness and magic. Already the first scene illustrated the interpretation of A Midsummer Night's Dream as theatrical performance. The audience saw a miniature of the Globe theatre around which live actors began to act out the play only to, after a while - by means of theatre convention - shift the action to the miniature Shakespearian scene. Marionettes entered the Globe and spectators took in its tininess and fragility. And then, this theatre became the court of Theseus. Yet the intertwining actions turned out to be just an act of theatrical foreplay. Once the supernatural powers entered the world of humans, the small Elizabethan stage disappeared and the theatre space expanded. At its centre, there was an intriguing and somewhat bizarre object: a glass box - neither a fish tank nor a museum display case - symbolizing the Athenian forest which turned out to be a space 'in between' - it linked the world of hand puppets representing people (Lysander and Hermia, Demetrius and Helena) with the realm of marionette ghosts and fairies (Oberon, Puck, Titania). In this way reality, as it were, grew from the ground and fantasy streamed down from the sky. A reviewer aptly interpreted this, enclosed in glass, scene:

In our homes aquaria and terrariums are particular bubbles, ambassadors of lands inhabited by poisonous snakes, rickety stick insects or fabulous underwater creatures, lands whose constitutions consist of impulses of desires and imperatives of instincts and not human norms or social contracts [...]. (LEGOŃ 2013: 63)

It was here that madness overtook the heroes who became helpless in the face of mysterious forces which steered them against their will and outside their consciousness. Eroticism and desire boiled in this glass aquarium, overflowed its edges and their waves reached all layers of this intricate performance. 


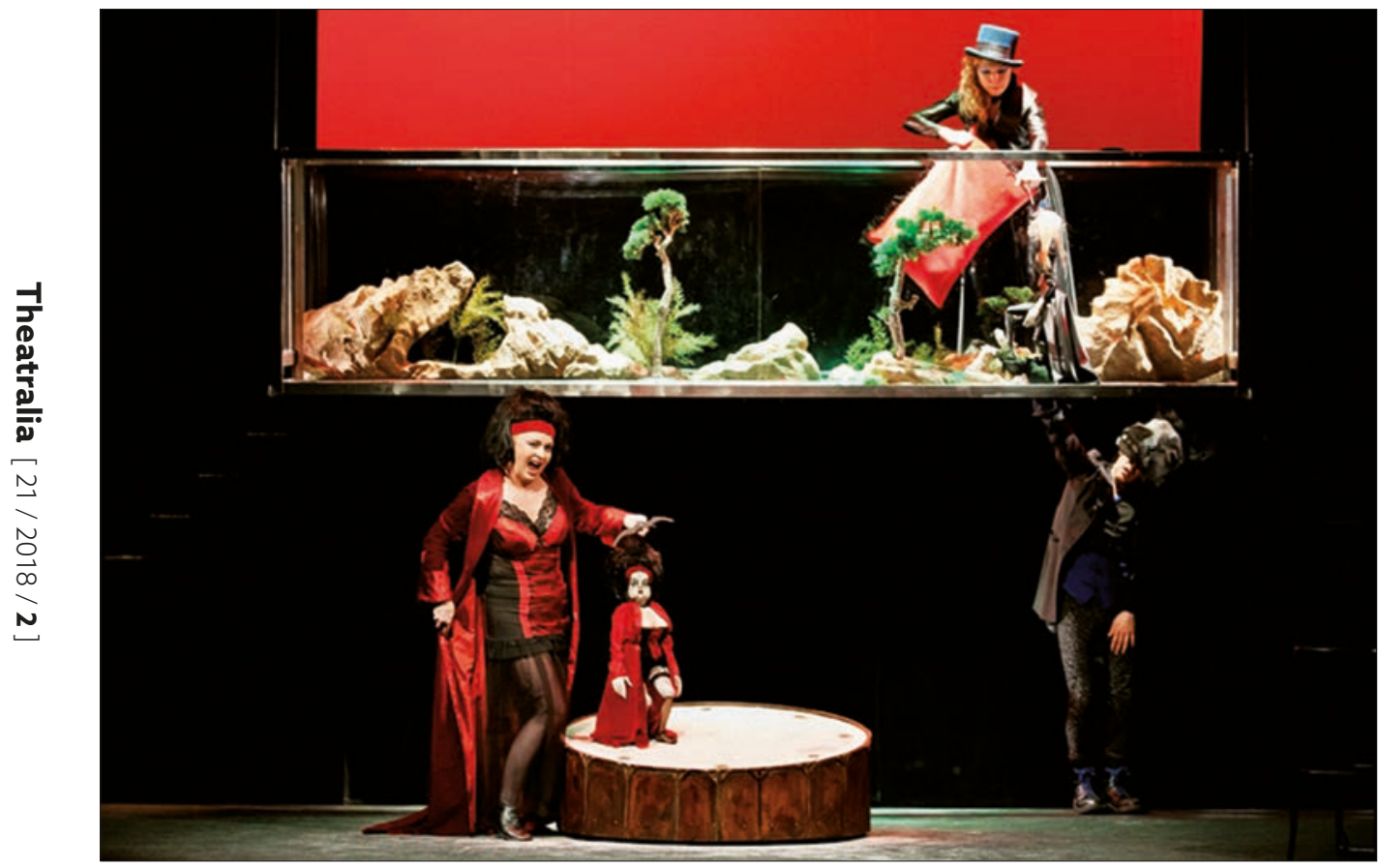

Fig. 7: Pecko: Puppet Theatre 'Banialuka', Bielsko-Biała 2013 the author: Dariusz Dudziak, the source: archive of the "Banialuka" Theater.

Make-up and costumes are kept in contemporary grotesque convention. Titania and the puppet personifying her are dressed in red and black tight-fitting bodices resembling courtesan's attire, Oberon's overgrown nose arouses ambiguous associations. Puck and the queen's fairy, dressed in black latex coats, ran on stage with a cigar and a hip flask. The costumes combined with the play of lights and stage design [...] are such that the unbridled sexuality of the characters is not cheap pornography but just the opposite - an affirmation of life. (KUBAS 2013)

Scenes with craftsmen rehearsing and playing the tragically funny story of Pyramus and Thisbe were play in pure form - startling and hilarious in its ambiguity was the casting of an actress as Snout playing the part of the chink of a wall, in Shakespeare's words, or simply a wall with a hole.

It was within the actors' realm, which complemented the puppets' reality, that more serious reflections on human existence, death and destiny appeared. For that purpose, the director and the author of musical settings, Róbert Mankovecký, used songs sung in English. This Brechtian idea of epic theatre worked amazingly well in Pecko's production and proved close to the Stratford master himself. The director's truth was probably best expressed by Titania's monologue. She put her puppet aside and spoke directly to the audience about apocalyptic changes in the world. The unexpected words of Titania turned into a description of disharmony and disintegration in our own world. When 
she spoke about floods, poisonous vapours, decaying crops, the omnipresence of death and the unpredictability of the seasons we felt that her discourse was not at all about the effects of jealousy and the conflicts of fairies but about our human participation in destabilising eternal natural laws. Thus, the content of the performance acquired additional meanings and the tale, bursting with eroticism, about various aspects of love revealed a sad reflection on the disintegrating order of our world.

The spectacle sold very well, the theatre was full, and the shows typically ended with ovations. Not only spectators appreciated the force and beauty of the performance which played to full audiences - the professionals also held it in high esteem as proven by several awards: honourable mentions at the XXVII All-Poland Puppet Theatres Festival in Opole, Animated Form Theatres International Festival Maskarada [Masquerade] in Rzeszów in 2015, a prestigious Silesian award Ztota Maska [Golden Mask] 2013 in performance for young audience category, and a certificate of quality of the Polish Center of UNIMA (Union Internationale de la Marionnette).

\section{Conclusion}

The above description of three productions of Shakespeare's A Midsummer Night's Dream is a form of documentation. My intention has been to draw Czech and Slovak researchers and critics' attention to the artistic work of Czech and Slovak artists working in Polish puppet theatres. It is represented by a great number of theatre productions. The following is a list of the most significant ones (TOMASZEWSKA 2014: 305-328; Elektroniczna Encyklopedia Teatru Polskiego):

\begin{tabular}{|l|c|c|c|}
\hline \multicolumn{1}{|c|}{ Artist* } & $\begin{array}{c}\text { Form of involvement } \\
\text { in the production }\end{array}$ & $\begin{array}{c}\text { Years of artistic work } \\
\text { covered by the study }\end{array}$ & $\begin{array}{c}\text { Number of theatre } \\
\text { productions }\end{array}$ \\
\hline Karel Brožek (CZ) & Mise-en-scène & $1977-2012$ & 15 \\
\hline Petr Nosálek (CZ) & Mise-en-scène & $1993-2013$ & 69 \\
\hline Marián Pecko (SK) & Mise-en-scène & $1995-2016$ & 28 \\
\hline Josef Krofta (CZ) & Mise-en-scène & $1975-2004$ & 6 \\
\hline Jakub Krofta (CZ) & Mise-en-scène & $2006-2016$ & 14 \\
\hline Onderj Spišak (SK) & Mise-en-scène & $1994-2016$ & 21 \\
\hline Marek Zákostelecký (CZ) & Mise-en-scène & $2005-2016$ & 15 \\
\hline Eva Farkašová (SK) & and scenography & & 102 \\
\hline Pavel Hubička (CZ) & scenography & $1995-2016$ & 114 \\
\hline Ján Polívka (CZ) & scenography & $1995-2016$ & 81 \\
\hline
\end{tabular}

* The list includes only the artists who started their work in Poland from puppet theatre and have completed the greatest number of theatrical productions in Poland. 
However, the Brno Theatralia Conference of 2016 was focused on the topic of Czech and Slovak scenography for Shakespeare - and this has determined my choice of the productions presented. I also focused on the form of the spectacles, mentioning their good reception only in the margins.

Shakespeare's plays have not often been presented in puppet theatres in Poland, which omission resulted from the general assumption that puppet theatre was meant for the children's repertoire. This held true for all the countries behind the Iron Curtain. It is worth noting that the first puppet premiere of A Midsummer Night's Dream in Poland took place already in 1965. Therefore, it seemed to me that juxtaposing that production with the contemporary proposals of J. Krofta (2003) and M. Pecko (2013) could be an interesting context, pointing to the possibility that the puppet theatre in Czech Republic and Slovakia, represented by these two productions, took inspiration from Polish theatre solutions. ${ }^{18}$ It is not difficult to notice that the theatrical form used by Dorman, which combines a variety of means of expression and conventions in one spectacle is visible in the ways of creating theatre by Krofta and Pecko, especially in the approach to theatrical substance. It is worth mentioning that J. Dorman published a cycle of articles (DORMAN 1966, 1967, 1968a, 1968b, 1968c) in which he described his creative method, and one of the articles was devoted to his work on A Midsummer Night's Dream (DORMAN 1967b: 231-234).

However, this topic is too broad and multi-faceted for it to be considered in the above discussion. It is my hope, however, that the three productions of A Midsummer Night's Dream discussed here give origin to a discussion about Polish, Czech and Slovak artistic cooperation, which is significant for all three puppet theatre traditions.

\section{Bibliography}

BAČOVÁ KROFTOVÁ, Jana. 2004. Sen Noci Svatojánské [online] 2004 [accessed: 23. 9. 2016]. Available online at http://www.janabacovakroftova.com/index.php?/theatres/sen-nocisvatojanske/

BITKA, Zbigniew. (ed.). 2008. Ludzie i lalki. Opowieści o teatrze [People and Puppets. Theatre Tales]. Opole: OTLiA, 2008.

BITKA, Zbigniew. 1997. Opolski Teatr Lalki i Aktora im. Alojzego Smolki, 1937-1997 [Antonin Smolka Opole Actor and Puppet Theatre]. Opole: OTLiA, 1997.

DOLENSKÁ, Kateřina. 2010. Mapa czeskiego lalkarstwa [A Map of Czech Puppetry]. Teatr Lalek [Puppet Theatre] (2010): 1.

DORMAN, Jan. 1966. Bábka v inscenácii. Umelecké Slovo (1966): 3.

18 I described the mutual inspirations and influences of Polish and Czechoslovak puppet theatre traditions, and the artistic contacts in my book Tam $i$ z powrotem. Rzecz o lalkarskich kontaktach polsko-czechostowackich i polsko-czesko-stowackich na Ślasku [There and Back: the thing about Polish-Czechoslovak and Polish-CzechSlovak relations in Silesia]. It should be recognized that this is the first study of this topic and as such is, by nature, a pioneering work. The summary of the book has also been published in the Czech language (Loutkár [The Puppeteer] 1 (2017): 24-27). 
DORMAN, Jan. 1967a. Rekvizity v mojom divadle. Umelecké Slovo (1967): 2.

DORMAN, Jan. 1967b. Shakespeare v mojom divadle. Umelecké Slovo (1967): 6.

DORMAN, Jan. 1968a. Bábka v inscenácii. Československý Loutkář (1968): 9.

DORMAN, Jan. 1968b. Herodove hry a moje divadlo. Umelecké Slovo (1968): 3.

DORMAN, Jan. 1968c. Poznamku režisera - anekdota Konik. Umelecké Slovo (1968): 9.

DORMAN, Jan. Letter dated 12. 12. 1971, typescript, Jan Dorman Archives, Zbigniew Raszewski Theatre Institute in Warsaw.

Elektroniczna Encyklopedia Teatru Polskiego [online]. (C2015. Available online at http://encyklopediateatru.pl/

FARKAŠOVÁ, Eva. 2011. Divadlo má zostat̉ na lud’och (Miloš Krekovič’s interview with Eva Farkašová). SME.kultura [online] (12. 5. 2011) [accessed: 18. 12. 2013]. Avalaible online at http://divadlo.sme.sk/c/5885180/eva-farkasova-divadlo-ma-zostat-na-ludoch.html

GARDNER, Lyn. 2013. Why children's theatre matters. The Guardian [online] (23. 10. 2013) [accessed: 11. 3. 2018]. Avalaible online at https://www.theguardian.com/stage/theatreblog/2013/oct/23/why-childrens-theatre-matters

JURKOWSKI, Henryk. 1965. Polski teatr lalek [Polish Puppet Theatre]. Teatr Lalek (25 lat PRL) [Puppet Theatre (25 years of PRL)]. 1965: 1-4.

JURKOWSKI, Henryk. 2002. Metamorfozy teatru lalek w XX wieku [The Metamorphoses of Puppet Theatre in the 20th Century]. Warsaw: Oficyna Wydawnicza „Errata”, 2002.

KOZIEŃ, Lucyna. (red.). 1992. Bielskie festiwale lalkowe [The Bielsko puppet festivals]. Teatr Lalek Banialuka [Banialuka Puppet Theatre]. Bielsko-Biała, 1992.

KROFTA, Josef. 2004. Trzy po trzy [Three by Three]. Interview with Josef Krofta. Życie Warszawy (4. 3. 2004).

KUBAS, Aleksandra. 2013. Szekspir nasz współczesny [Shakespeare our Contemporary]. Dziennik Teatralny [Theatre Journal] Bielsko-Biała [online] (29. 5. 2013) [accessed: 8. 8.2016]. Avalaible online at http://www.dziennikteatralny.pl/artykuly/szekspir-nasz-wspolczesny.html

LEGOŃ. Janusz. 2013. Igraszki na krawędzi otchłani [Frolicking At the Edge of an Abyss]. Teatr Lalek [Puppet Theatre] (2013): 4.

SMETANA, Radek. 2012. Mým celoživotním tématem je divadlo! Radek Smetana’s conversation with M. Pecko. Divadelni zpravodaj 9 (2012). Available online at http://www.vcd.cz/old/html/ staryweb/hry/sennoci.php [accessed: 26. 9. 2016].

Pl. Spektakl dla dorosłych we Wrocławskim Teatrze Lalek [A Spectacle for Grown-ups At the Wrocław Puppet Theatre]. Gazeta Wyborcza (24. 1. 2004).

TOMASZEWSKA, Eva. 2004. Teatr Jana Dormana w świetle kontaktów z czechosłowackim środowiskiem lalkarskim w latach 1955-1967 [Jan Dorman's Theatre in the Light of his Contacts with Czechoslovak Puppetry Circles in the Years 1955-1967]. In O divadle na Moravě a ve Slezsku [Theatre in Moravia and Silesia]. Olomouc: Palacký University, 2004.

TOMASZEWSKA, Eva. 2012. Jan Dorman, wtasna droga [Jan Dorman, His Way]. Katowice: Wydawnictwo Naukowe Śląsk, 2012.

TOMASZEWSKA, Eva. 2013. Teatr to przestrzeń wolności [Theatre Is a Space of Freedom]. E. Tomaszewska's interview with K. Brožek. Magazyn Kulturalny MOST [MOST Cultural Magazine] (2013): 6-7.

TOMASZEWSKA, Eva. 2014. Tam $i$ z powrotem. Rzecz o lalkarskich kontaktach polsko-czechostowackich i polsko-czesko-stowackich na Ślasku [There and Back, On the Polish-Czechoslovak and Polish-CzechSlovak Puppet Affiliations in Silesia]. Katowice: Wydawnictwo Uniwersytetu Śląskiego, 2014.

TOMASZEWSKA, Eva. 2017. Polsko-česko-slovenské loutkářské kontakty ve Slezsku [Polish-Czech- 
Slovak puppet contacts in Silesia]. Loutkář [The Puppeteer] (2017): 1.

WASZKIEL, Marek. 2012. Dzieje teatru lalek w Polsce 1944-2000 [History of Puppet Theatre in Poland 1944-2000]. Warsaw: Akademia Teatralna im. Aleksandra Zelwerowicza [Aleksander Zelwerowicz Theatre Academy], 2012.

\section{Ewa Tomaszewska, Ph.D.}

Institute of Ethnology and Education, Silesian University, Cieszyn, Poland tomaszewska.ewa61@gmail.com

Ewa Tomaszewska was born in Katowice in 1961, graduated in architecture from the Polytechnic of Krakow in 1986 and then in the stage management study (specialisation - puppet theatre) from the Theatre Academy in Warsaw (1990). She participated in different workshops e.g. with Peter Schumann from Bread and Puppet Theatre, Henk Boervinkel from Figurenteater 'Triangel' and Richard Bradshow. She has created performances for children at different Polish theatres in Białystok, Toruń, Łódź and Bielsko-Biała. Since 1990 she has worked at the Institute of Ethnology and Education in the Silesian University in Cieszyn where she has organised different theatrical courses. She has also prepared many performances with students under the Student's Scene which she established at the university. For 12 years she has been engaged in doing theatrical experiments concerning problems of theatre - art creation and reception of theatre form for and by children and teenagers. She is also the author of two books on Jan Dorman, original polish creator of artistic theatre for young audience (Jan Dorman, poeta teatru, 2010; Jan Dorman - własna droga, 2012) and author of the book about the Polish - Czechoslovak and Polish - Czech - Slovak puppetry theatre contacts in Silesia - the mutual inspiration and influences and their impact on the contemporary Czech, Slovak and Polish puppetry theatre (Tam i z powrotem. Rzecz o lalkarskich kontaktach polsko-czechosłowackich i polsko-czesko-słowackich, 2014). 